\title{
Inter-Laboratory Comparison of Multi-Allergen- Specific Immunoglobulin E Screening Assay Using Polycheck Allergy Diagnostic
}

Young Ae Lim

Department of Laboratory Medicine, Ajou University School of Medicine, Suwon, Korea

Corresponding author: Young Ae Lim

Department of Laboratory Medicine, Ajou University School of Medicine, 164 World cup-ro, Yeongtong-gu, Suwon 16499, Korea

Tel: +82-31-219-5786

Fax: +82-31-219-5778

E-mail: limyoung@ajou.ac.kr

pISSN: 2384-2458

elSSN: 2288-7261
Background: Currently there is no external proficiency testing program for allergen-specific immunoglobulin E assays (sIgE) in Korea. The aim of this study was to evaluate the accuracy of sIgE performed in different laboratories in Korea using Polycheck Allergy Diagnostic (Biocheck GmbH, Germany) or simply 'Polycheck' and to further perform an inter-laboratory comparison of sIgE.

Methods: Three inter-laboratory trials were undertaken from June 2016 to December 2017 at nine institutions. Serum samples obtained from three patients who had a history of positive Polycheck results were used in each trial. A total of 59 allergens were evaluated from the standard panel, inhalation panel, and food panel. The acceptable rates (\%) of classes 0-6 of the results were calculated using three different criteria, including the consensus of $80 \%$ participants of the College of American Pathologists (CAP), the most frequent value (MFV), and the Overall Misclassification Index Score (OMIS).

Results: The proportion of laboratories that showed acceptable results for CAP criteria, MFV, and OMIS were around 93.0\%-97.7\%, 66.3\%-76.0\%, and $0.1-1.3$, respectively, in each trial. Under-performing institutes showed consistently higher $(49 / 68,72.1 \%)$ or lower $(19 / 68$, 27.9\%) than acceptable results for all criteria.

Conclusions: This is the first study evaluating the inter-laboratory variation of sIgE in Korea using various criteria. It was found that the acceptable rate could be altered based on changes in these criteria. These findings might be useful for the inter-laboratory comparison of sIgE in Korea in the future as well.

(J Lab Med Qual Assur 2019;41:39-46)

Key Words: Laboratory proficiency testing, Allergen-specific immunoglobulin E, Quality control

Received November 21, 2018, Revision received January 31, 2019, Accepted February 8, 2019
서론

알레르기 진단 시 원인이 되는 알레르겐을 검출하는 것은 중 요하다. 고전적인 진단방법으로 알려진 피부단자시험은 검사 방법 및 결과해석의 표준화가 어렵고 항히스타민제 등의 약 물을 복용하거나 피부질환이 있는 환자에게는 검사를 실시할 수 없다는 단점이 있다[1]. 이에 비하여 혈청 알레르겐 특이 immunoglobulin $\mathrm{E}(\mathrm{IgE})$ 항체 측정법은 간편하면서도 피부 단자시험의 단점을 보완할 수 있다는 장점을 가지고 있어 현재 선별검사로 널리 사용되고 있다. 검사법도 방사선면역측정법
에서 최근에는 비교적 다루기 편리한 효소면역측정법 혹은 화 학발광면역분석법으로 치환하게 되어 더욱 검사가 편리하게 되었다.

혈청 알레르겐 특이 $\mathrm{IgE}$ 항체 측정법은 시약의 알레르겐 구 성에 따라 크게 두 가지로 나뉠 수 있는데, 알레르겐마다 개별 로 개발되어 의심되는 특정 알레르겐 특이 $\operatorname{IgE}$ 항체의 검출을 위한 개별검사와 다중 알레르겐 패널을 이용하는 선별용 패널 검사이다. 이 중 Polycheck Allergy Diagnostic (Polycheck; Biocheck GmbH, Münster, Germany)는 다중 알레르겐 선 별용 패널검사로 국내에서 이미 다른 선별검사에 비하여 동등 


\section{Journal of LABORATORY MEDICINE and QUALITY ASSURANCE}

\section{Young Ae Lim • Inter-Laboratory Comparison Using Polycheck}

하거나 우수한 것으로 평가되었다[2,3]. Polycheck는 각각 20 개의 알레르겐으로 구성된 카세트 형태로 총 $\mathrm{IgE}$ 를 포함한 한 국형 I 표준형(표준형), 한국형 II 흡인 선별용(흡입용), 한국 형 III 식품 선별용(식품형)의 3가지 카셋트 형태로 구성되어 총 IgE를 포함하여 60가지의 알레르겐을 선별할 수 있다.

알레르겐 특이 $\operatorname{IgE}$ 항체 시약들은 제조회사마다 시약 의 알레르기항원 성분이 다르고, 정량 보정방법, 검출방법 이 다르므로 알레르겐 특이 $\mathrm{IgE}$ 항체 결과가 시약 간에 다 를 수 있기 때문에〔3] 다른 시약들 간의 결과를 비교할 경우 에는 주의하여야 한다. 또한 세계보건기구(World Health Organization, WHO) 산하의 생물학적표준화전문위원회 (Expert Committee on Biological Standardization)에서 일 부 알레르겐에 대한 WHO international biological reference preparations를 제조하였기는 하나[4], 이의 종류가 워낙 다 양하고 항원추출물을 사용하는 검사법의 특성 때문에 알레르 겐 특이 $\mathrm{IgE}$ 항체의 표준화 작업은 쉽지 않은 실정이다. 따라 서 각 검사실에서는 시약제조회사에서 제공하는 calibrator를 사용하여 주기적인 보정을 하고 내부 정도관리와 외부숙련도 조사를 통하여 결과의 정확성을 유지하도록 권고하고 있다.

그럼에도 불구하고 시약 간에 다양한 결과를 보이기 때문에 현재 국내에서 검체 검사에 대하여 외부숙련도조사사업을 담 당하는 진단검사의학회와 대한임상검사정도관리협회에서는 알레르겐 특이 IgE 항체에 대한 외부숙련도조사가 아직 없는 실정이다. 다만 특정 국내 시약제품에 한하여 그 제품을 사용 하고 있는 국내 검사실에 한하여 외부숙련도조사가 일부 진행 되고 있는 것을 제외하고는 국내 외부숙련도조사사업이 진행 되고 있지 않아 검사실 간 비교 평가가 어려운 실정이다. 물론 일부 대형병원에서는 국내가 아닌 외국에서 주관하고 있는 알 레르겐 특이 $\mathrm{IgE}$ 항체에 대한 외부숙련도조사에 참여하고 있 으나 많은 국내 기관에서는 참여하고 있지 못하는 실정이다.

이에 본 연구에서는 국내에서 Polycheck 제품을 공급하는 주식회사 원메디칼의 요청에 의하여 외부숙련도조사 목적으 로 검사실 간 비교 평가용 물질을 제조하고 국내에 Polycheck Allergy Diagnostic 제품을 사용하고 있는 병원에 발송하고 그 결과를 다앙 기준들로 분석하였기에 향후 알레르겐 특이 $\mathrm{IgE}$ 항체 검사의 검사실 간 평가 시 기준 선정에 도움을 주고자 하 였다.

\section{재료 및 방법}

\section{1. 대상}

이 연구는 검체 공여자 선정을 위하여 아주대학교병원 생명
윤리심의위원회의 승인을 득한 후 진행하였다(AJIRB-DEVSUR-16-156). 비교평가용 물질 제조를 위한 검체 공여자 선 정기준은 진료를 위하여 통상검사로서 Polycheck 다중 알레르 겐 특이 $\mathrm{IgE}$ 항체 검사가 의뢰된 검체 중 다중 알레르겐에 양 성을 보여 검사실 간 비교 목적을 위한 물질제조에 적합한 경 우라고 연구자가 판단한 경우로 한정하였다. 만 19세 이상의 성인으로 국내 $400 \mathrm{~mL}$ 전혈 헌혈자 기준을 충족하며 체내 혈 액의 $2 \%$ 미만인 $66 \mathrm{~mL}$ 를 채혈하여도 무리가 없을 것으로 여 겨지는 전신상태 양호한 성인으로 하였다. 이들 중 검체 제공 에 동의하여 설명문 및 동의서에 서명한 피험자에 한하여 전혈 을 채혈하였다. 총 3회 발송을 목표로 발송 시마다 한 명의 피 험자로부터 유래된 검체를 채혈하여 제조하였다.

검사실 간 비교 평가에 참여할 기관은 Polycheck 제품을 공 급하는 주식회사 원메디칼에서 각 기관에 안내를 하여 참여 의사를 밝힌 기관들로 한정하였다. 항목은 총 $\mathrm{IgE}$ 를 포함하여 Polycheck 제품의 표준형 20개, 흡입형 20개, 식품형 20개로 총 $\mathrm{IgE}$ 를 포함한 60 개 알레르겐이 포함된 3 가지 종류의 스트 립을 평가하였다.

\section{2. 연구설계}

\section{1) 검사실 간 비교 평가용 물질 제공자 선정}

연구자가 피험자 조건에 적합한 이들이라고 판단되면 통상 검사를 의뢰한 임상의사들에게 연락을 취하여 피험자를 검사 실에 방문하게 하여, 연구 참여에 대한 설명을 듣고 동의를 한 자에 한하여 채혈을 실시하였다. 채혈된 검체는 원심분리 후 혈청을 여러 개로 분주하여 표식한 후 $-70^{\circ} \mathrm{C}$ 에 보관하였다.

\section{2) 검사실 간 비교 평가용 물질 제조 및 공급}

평가 시마다 이미 보관된 혈청을 녹여 각 시험관에 분주(1$1.5 \mathrm{~mL}$ )하고, 익명화된 용기 표식, 검수 및 아이스팩 포장작 업을 시행한 후 우체국 익일 등기 배송 시까지 냉장보관한 후 검체를 배송하였다. 검체 발송 1 주일 전에 참여기관에 안내문 을 먼저 발송하여 안내를 실시하였다.

\section{3) 검사실 간 비교 평가결과 분석 및 배포}

검체 발송 3 주일 이내로 답변을 회신받고 2 달 이내로 분석 하여 결과를 참여기관의 메일로 회신하였다. 참여기관의 회신 결과를 바탕으로 총 $\mathrm{IgE}$ 를 제외한 59 개 알레르겐에 대한 각 항 목을 등급(class) 0 부터 6 까지의 결과를 분석하였다. 부적합 은 허용범위 이외의 결과를 보이는 등급으로 정의하였으며, 각 기관별 참여기관의 결과는 익명으로 이메일로 분석결과를 발 


\section{Journal of LABORATORY MEDICINE and QUALITY ASSURANCE}

\section{Young Ae Lim et al • Inter-Laboratory Comparison Using Polycheck}

송하였다. 등급의 허용범위는 회차 시마다 일부 차이가 있었 지만 본 연구를 위한 최종 분석 시는 허용범위를 통일하기 위 하여 3가지 기준으로 평가하였다. 미국병리협회(College of American Pathologists, CAP)의 Multiple Allergen Screen 의 2018 년 기준처럼 참여기관의 $80 \%$ 합의(consensus) 이 상, 1997년 유럽 외부숙련도평가 보고에서 사용한 Overall Misclassification Index Score (OMIS) [5], 그리고 오스트리 아의 25년간의 외부숙련도평가 결과 분석에서 사용된 Koch 와 Aberer [6]의 기준을 사용하였다. 비록 CAP에서는 참여 기관이 10 개 이상인 경우에 통계분석을 실시하고 5 개 이상인 경우에는 중앙값, 최고 및 최저값만을 나타내고 있으나 본 연 구에서는 참여기관이 모두 10 기관 미만이었으나 평가를 위하 여 $80 \%$ 합의 이상을 기준으로 삼았다. $\mathrm{CAP}$ 기준의 적합률 은 매 회차 59 개 항원을 분모로 적합한 항원 수를 분자로 하 여 산정하였다. Misclassification Index Score (MIS) 지수는 각 항원마다 등급 0 과 1 은 음성이고 그 이상의 등급은 양성으 로 간주하고 참여기관의 $80 \%$ 이상의(원래는 $90 \%$ 이상이나 본 연구는 참여기관 수가 적으므로 $90 \%$ 이상이려면 모든 기 관의 답변이 일치하여야 하므로 수정함) 합의를 얻은 음성 혹 은 양성 결과를 최종 정답으로 하되 정답기관은 0 점, 오답기 관은 1점을 주는 방식으로 모든 항원의 MIS 값의 합을 OMIS 로 정의하였다. Koch와 Aberer [6]의 기준은 최빈도 값(most frequent value)을 허용범위로 정의하되, 최빈도 \pm 1 등급 혹은 2 등급까지도 가능한 허용범위로 분석하였다. 또한 양성 검체 의 경우 절대 정답에서 2 등급 초과이거나 음성으로 답변한 경 우와 음성 검체의 경우 양성으로 보고한 경우를 부적합 결과로 정의하여 부적합률을 산정하였다.

2 차와 3 차 평가에서는 검사실 간 차이를 보이거나 일부 확인이 필요하였던 알레르겐 특이 $\mathrm{IgE}$ 항체 항목 중 $\mathrm{Im}^{-}$ munoCAP (Pharmacia Diagnostics AB, Uppsala, Sweden) 으로 확인이 가능하였던 항목에 대해서는 ImmunoCAP 검 사를 시행하였다. 이 경우 ImmunoCAP 결과까지 참여 기관에 공지하되, Polycheck의 f24/440 (Shrimp Mix)는 ImmunoCAP에서는 f24으로 항원 조성이 일부 다름으로 결과 값이 다를 수 있음을 함께 공지하였다.

\section{4) 통계방법}

자료는 Excel professional plus 2010 프로그램(Microsoft Corp., Redmond, WA, USA)로 정리하였고, 통계분석은 SPSS ver. 12.0 for Windows (SPSS Inc., Chicago, IL, $\mathrm{USA}$ )을 사용하여 분석하였다. 3 회의 평가 동안 참여한 7 기관 들의 회차 간 결과 비교는 Friedman Test로 검증하였고, 각
기준평가방법에 따른 3 회차 동안의 모든 정답률의 상관관계는 Pearson correlation으로 분석하였다. $P<0.05$ 인 경우 유의한 차이가 있는 것으로 간주하였다.

\section{5) 평가 후 조치}

모든 참여기관들은 정기적으로 시약 공급업체로부터 정기 점검을 받았으나, 매 회차 평가 후 1 개 이상의 항목에서 허용 범위를 벗어난 결과를 보인 기관에 대해서는 추가로 시약 공 급업체가 기기점검을 실시하였고 점검 후 상품화 대조물질로 (Control-Sample for I-Standard Panel, Biocheck GmbH) 확인을 실시하였다. 기기 점검 시는 튜빙에 대한 세척(필요 시 교환), 카메라 모듈, $\mathrm{x} / \mathrm{y}$ 축과 모듈에 대한 점검(크리닝, 필요 시는 교체 및 기름 칠 등), 칼리브레이션 등 실시, 펌프에 대한 점검, 팁 교체 등이 포함되었다.

\section{3. 검사방법}

\section{1) Polycheck 검사}

방법은 전용 자동화 장비를 이용하여 시약설명서에 준하였 고, 간략히 소개하면 다음과 같다. 특이 알레르겐이 부착된 카 세트의 nitrocellulose 막 위에 혈청 $200 \mathrm{uL}$ 을 분주, 항-IgE를 분주, 효소 표지 접합체를 넣었는데, 각 단계마다 반응 후 세척 하였다. 여기에 발광시약을 넣으면 검체 내 특이 $\mathrm{IgE}$ 의 농도에 비례하여 발색하는데, 발색 강도는 스캐너로 판독되어 5 개의 calibrator 결과값에 근거하여 Biocheck Image Software 프 로그램이 스캔한 이미지를 정량 분석하였다. 결과치는 $\mathrm{kU} / \mathrm{L}$ 로 나타내었으며, $>100 \mathrm{kU} / \mathrm{L}$ 은 $100 \mathrm{kU} / \mathrm{L}$ 으로 간주하였다. 총 소요시간은 2 시간 40 분이었으며 정량 결과값과 등급을 0-6 을 산출하는데, 정량값은 $0.35 \mathrm{kU} / \mathrm{L}$ 이상, 등급 1 이상을 양성 으로 판정하였다.

\section{2) ImmunoCAP}

방법은 전용장비인 ImmunoCAP250 (Pharmacia Diagnostics $\mathrm{AB}$ )과 및 알레르겐 특이 $\mathrm{IgE}$ 전용시약을 이용하 여 시약설명서에 준하여 검사를 시행하였다. 즉 혈청 $40 \mathrm{uL}$ 를 알레르겐이 결합되어 있는 ImmunoCAP 캡슐과 반응 후 세 척, 효소 표지 항- $\operatorname{IgE}$ 를 넣고 반응 후 세척하고, 형광발색시약 을 넣어 반응시킨 후 형광 정도를 농도로 전환하여 정량 분석 하였다. 결과치는 $\mathrm{kU} / \mathrm{L}$ 로 나타내었으며, $>100 \mathrm{kU} / \mathrm{L}$ 은 100 $\mathrm{kU} / \mathrm{L}$ 으로 간주하였다. 총 소요시간은 약 2 시간이며 정량 결 과값과 등급을 $0-6$ 을 산출하는데, 정량값은 $0.35 \mathrm{kU} / \mathrm{L}$ 이상, 등급 1 이상을 양성으로 판정하였다. 


\section{Journal of LABORATORY MEDICINE and QUALITY ASSURANCE}

\section{Young Ae Lim • Inter-Laboratory Comparison Using Polycheck}

\section{결과}

검사실 간 비교 평가가 이루어진 참여기관 수는 총 9 개로 3 회 모두 참석한 기관은 7개였으며 시기는 다음과 같다. 2016 년 11월 9기관, 2017년 5월 8기관, 2017년 10월 7기관 총 3차 례에 걸쳐 시행하였다. 피험자는 물질제조에 적합하다고 확인 된 3 명의 성인을 선정하여 각 회차별 평가당 1 명의 피험자 혈
액을 사용하였다. 참여한 모든 기관이 흡입형, 식품형, 그리고 표준형에 참여하였으나, 3 회에 참여한 기관 중 한 기관은 식품 형과 표준형에만 참여하였다.

각 회차별 59 개 알레르겐 항원 평가에서 $\mathrm{CAP}$ 기준 적용 시 정답률의 평균은 1차 $94.7 \%, 2$ 차 $97.7 \%$, 그리고 3차 $93.0 \%$ 였으나 3회 모두 참여한 7기관들의 회차별 정답률의 차이 는 없었다 $(P=0.53)$. Koch와 Aberer [6]의 최빈도 값만을

Table 1. Percentage (\%) of allergens from participating laboratories showing unacceptable results using Polycheck Allergy Diagnostic during three trials

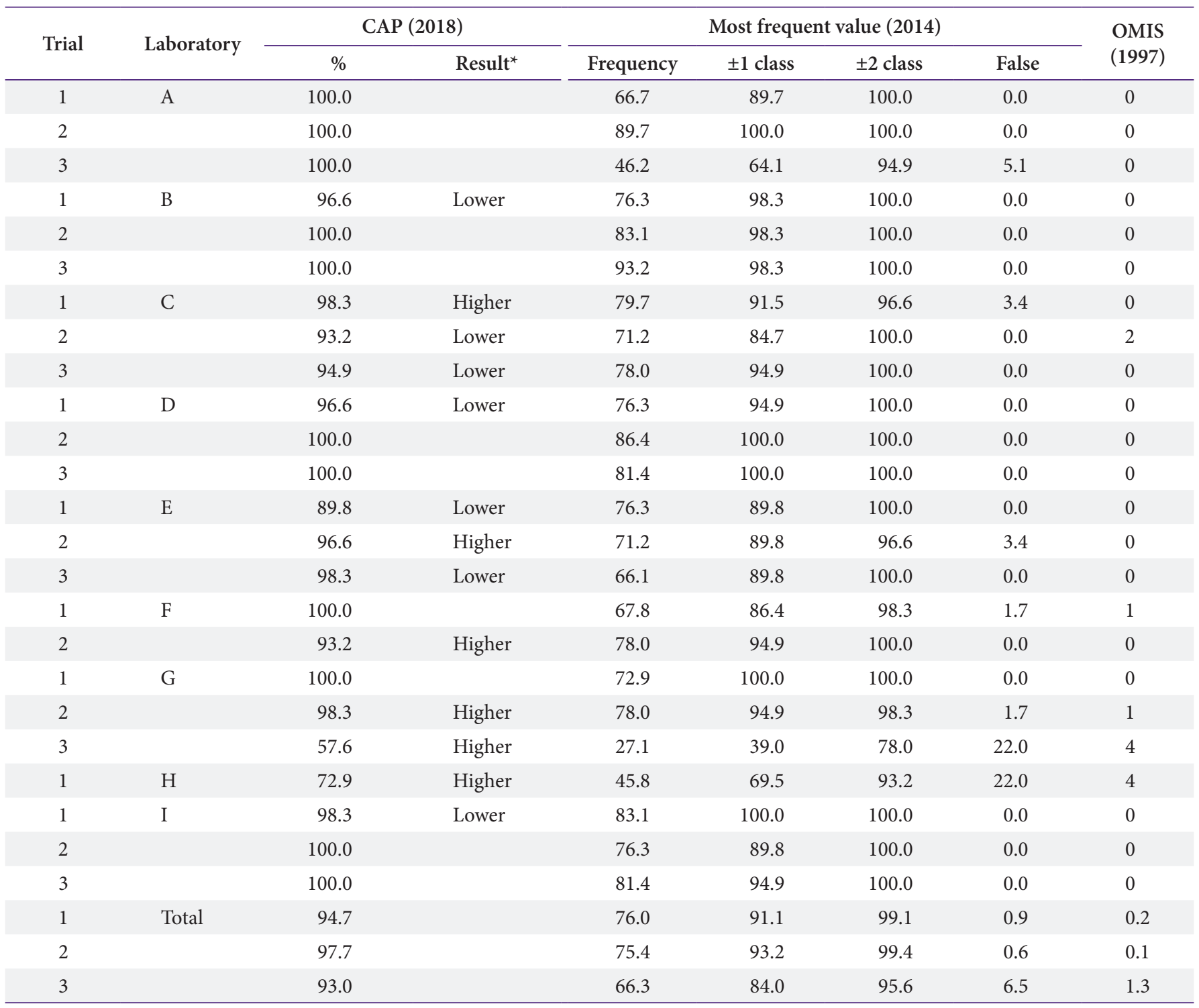

CAP, consensus of $80 \%$ participants from the College of American Pathologists; most frequent value, using criteria based on the results of 25 years of external quality assessment in Austria [6]; and OMIS, using criteria from external proficiency testing carried out in Europe in 1997 [5]. Abbreviations: CAP, College of American Pathologists; OMIS, Overall Misclassification Index Score.

*All grades of unacceptable results from under-performing institutes were consistently higher or lower as compared to the acceptable results obtained from compliant laboratories. 
허용기준으로 적용 시 정답률과 부적합률의 평균은 각각 1 차 $76.0 \%$ 와 $0.9 \%, 2$ 차 $75.4 \%$ 와 $0.6 \%$ 그리고 3 차 $66.3 \%$ 와 $6.5 \%$ 였으나 3 회 모두 참여한 7 기관들의 회차별 정답률의 차 이는 없었다 $(P=0.65)$. OMIS 지수의 평균은 1 차 $0.2,2$ 차 0.1 , 그리고 3 차 1.3 으로 증가하였으나 3회 모두 참여한 7기 관들의 회차별 OMIS 지수의 차이는 없었다 $(P=0.37)$ (Table $1)$.

$\mathrm{CAP}$ 기준을 적용할 경우 각 회당 오류를 보인 각 알레르겐 항목의 개수(기관 수)는 1 (4), 2 (3), 3 (1), 4 (2), 6 (1), 16 (1), 25 (1)으로 허용범위를 벗어난 경우가 68개였는데, 이 중 41 개는 2 개 기관으로부터 유래되었다. 부적합 결과를 보인 모 든 기관에서 부적합을 보인 양상은 다른 기관에 비하여 일괄 적으로 위양성 혹은 위음성 양상을 보여주었는데, 위양성이 $72.1 \%$ (49/68) 그리고 위음성이 27.9\% (19/68)를 차지하여 위양성이 더 많았다(Table 1).
3 회차 동안의 모든 정답률의 Pearson 상관계수는 $\mathrm{CAP}$ 기 준과 Koch와 Aberer [6]의 최빈도 기준 적용 시는 0.759 (P $<0.001), \mathrm{CAP}$ 기준과 Koch와 Aberer [6]의 최빈도 \pm 1 등 급기준 적용 시는 $0.798(P<0.001), \mathrm{CAP}$ 기준과 Koch 와 Aberer [6]의 최빈도土2 등급기준 적용 시는 $0.641(P$ $<0.001)$ 그리고 Koch와 Aberer [6] 기준의 부적합률과 OMIS 지수와의 상관계수는 $0.894(P<0.001)$ 로 가장 높았 다.

반면 총 $\operatorname{IgE}$ 를 포함한 59 개 알레르기 항원 중 부적합을 보 인 항원은 중복 항목을 제외하고는 43 개 항목이었다. 59 개 항원 중 $\mathrm{CAP}$ 기준으로 3 회차 모두에서 부적합 결과를 보 인 기관이 있거나 3회차 중 한번이라도 Koch와 Aberer [6] 의 기준에 의하여 3 등급 이상을 벗어난 기관이 있거나 혹 은 두 기준에서 2 회차 이상 부적합 결과를 보이면서 3 회 차 중 한번이라도 Koch와 Aberer [6]의 기준에 의하여 2 등

Table 2. Comparison of class results of Polycheck Allergy Diagnostic and ImmunoCAP

\begin{tabular}{|c|c|c|c|c|c|c|c|c|}
\hline \multirow{2}{*}{ Panel } & \multirow{2}{*}{ Code } & \multirow{2}{*}{ Item } & \multirow{2}{*}{$\begin{array}{c}\text { No. of } \\
\text { trial }\end{array}$} & \multirow{2}{*}{$\begin{array}{l}\text { No. of } \\
\text { partici- } \\
\text { pants }\end{array}$} & \multicolumn{2}{|c|}{$\begin{array}{c}\text { Class of Polycheck (no. of } \\
\text { participants) }\end{array}$} & \multicolumn{2}{|c|}{ ImmunoCAP } \\
\hline & & & & & Acceptable & $\begin{array}{l}\text { Unaccep- } \\
\text { table }\end{array}$ & Class & $\mathrm{kUA} / \mathrm{L}$ \\
\hline $\mathrm{S}$ & $\mathrm{f} 24 / 440$ & Shrimp mix & 3 & 7 & $0(6)$ & $2(1)$ & 1 & 0.51 \\
\hline $\mathrm{S}$ & f95 & Peach & 2 & 8 & $0(2), 1(2), 2(4)$ & (0) & 2 & 1.31 \\
\hline S & $\mathrm{e} 01$ & Cat epithelia & 3 & 7 & $3(2), 4(3), 5(1)$ & $6(1)$ & 3 & 5.86 \\
\hline S & $\mathrm{t} 02 / \mathrm{t} 03$ & Alder-Birch pollen mix & 2 & 8 & $2(8)$ & $(0)$ & 2 & 0.77 \\
\hline S & w01 & Ragweed pollen & 3 & 7 & $3(4), 4(1), 5(1)$ & $6(1)$ & 3 & 12.5 \\
\hline S & w06 & Mugwort pollen & 3 & 7 & $3(3), 4(2), 6(2)$ & $(0)$ & 3 & 8.16 \\
\hline I & g03 & Cocksfoot pollen & 3 & 6 & $3(3), 5(1)$ & $6(1)$ & 3 & 9.39 \\
\hline $\mathrm{F}$ & f04 & Wheat-flour & 2 & 8 & $1(2), 2(4), 3(1)$ & $0(1)$ & 2 & 1.57 \\
\hline $\mathrm{F}$ & f04 & Wheat-flour & 3 & 7 & $3(6)$ & $5(1)$ & 3 & 12.3 \\
\hline $\mathrm{F}$ & f11 & Buckwheat-flour & 2 & 8 & $0(5), 1(1), 2$ (2) & (0) & 2 & 1.39 \\
\hline $\mathrm{F}$ & $\mathrm{f} 11$ & Buckwheat-flour & 3 & 7 & $3(3), 4(2), 5(1)$ & $6(1)$ & 3 & 10.10 \\
\hline $\mathrm{F}$ & f13 & Peanut & 2 & 8 & $1(2), 2(5)$ & $3(1)$ & 2 & 2.06 \\
\hline $\mathrm{F}$ & f13 & Peanut & 3 & 7 & $4(3), 5(1), 6(3)$ & $(0)$ & 3 & 12.90 \\
\hline $\mathrm{F}$ & $\mathrm{f} 26$ & Pork & 3 & 7 & $\mathbf{0}(4), 1(2)$ & $2(1)$ & 0 & 0.25 \\
\hline
\end{tabular}

The instrument used was from the following company: Polycheck Allergy Diagnostic (Polycheck; Biocheck GmbH, Münster, Germany); ImmunoCAP250 (Pharmacia Diagnostics AB, Uppsala, Sweden). Bold type is the same class with that of ImmunoCAP.

Abbreviations: S, standard panel; I, inhalant panel; F, food panel. 


\section{Journal of LABORATORY MEDICINE and QUALITY ASSURANCE}

\section{Young Ae Lim • Inter-Laboratory Comparison Using Polycheck}

급 이상을 벗어난 항원들을 조사해 보았는데 다음과 같았다. 표준형에는 f14 (Soybean), e02/e05 (dog epithelia), d01 (Dermatophagoides pteronyssinus), w01 (ragweed pollen) 와 g06 (timothy grass pollen), 음식형에는 f04 (wheatflour), f11 (buckwheat-flour), f13 (peanut), f25 (tomato), $\mathrm{f} 47$ (garlic)와 citrus 혼합물, 흡입형에는 w08 (dandallon pollen), w12 (goldenrod pollen), k82 (latex), g03 (cocksfoot pollen), g04 (fescue meadow pol), g09 (redtop pollen), t04 (hazel pollen), w14 (pigweed) 그리고 Ash (ash mix)로 음 식형보다는 흡입형 항원이 더 많았다.

ImmunoCAP 검사는 중복을 포함하여 20개 항원에서 시 행하였는데 17개가 Polycheck의 허용범위와 ImmunoCAP 의 class 값이 일치하여 $85 \%$ 의 일치율을 보였고, 그 중 13 개 는 Polycheck의 허용범위 중 최빈도 값과 일치하였다. 그러 나 ImmunoCAP의 class 값이 일치하였으나 f24/440 (shrimp mix), 2회차의 g03 (Cocksfoot pollen), 3회차의 f13 (peanut) 은 참여기관의 허용범위와 ImmunoCAP의 class 값이 일치하 지 않았는데, 한 단계 정도의 차이를 보였다(Table 2).

\section{고찰}

$\operatorname{Lim}$ 등[7]이 2006년 국내 85개 검사실을 대상으로 알레르 기 관련 검사들에 대한 설문조사를 실시한 결과 61 개 기관에 서 검사를 실시하고 있었으며, 대부분의 검사실들은 검사키트 내에 포함된 내부정도관리만을 실시하고 있었으며, 정량보정 은 거의 실시하지 않고 있는 것으로 조사되어 외부숙련도조사 의 필요성을 지적하였다. 국내에서 비록 많은 기관이 참여한 것은 아니나, 국내에서 검체 검사의 외부숙련도조사사업을 담 당하는 진단검사의학회와 대한임상검사정도관리협회에서는 알레르겐 특이 $\mathrm{IgE}$ 항체에 대한 외부숙련도조사가 아직 없는 실정에서 본 연구에서 실시한 기관 간 평가는 외부숙련도조사 를 대치하는 데 도움을 줄 것으로 생각되었다. 오스트리아 25 년 결과 보고에서도 부적합률은 예전부터 참여하고 있던 기관 들이 신규 참여기관에 비하여 적었다고 보고하였는데[6], 이 러한 결과는 외부숙련도조사의 지속적인 참여가 검사실의 정 확성을 향상하게 하는데 기여할 수 있다는 증거를 보여준다고 볼 수 있다.

본 연구에서는 매회마다 9 기관 이하의 기관이 참여하였으므 로 한 명의 공여자로부터 $66 \mathrm{~mL}$ 의 전혈을 채혈하여도 무리 없 이 참여기관에 동일한 혈청을 제공할 수 있었다. 그러나 국내 기관을 대상으로 확대하고 한 명의 공여자로부터 물질을 획득 하여야 할 경우에는 헌혈 기준에 준하여 2 주 이상의 간격을 두
고 혈장성분채혈을 통하여 얻어야 가능할 것으로 생각되었다.

본 연구에서 정답률은 평가기준에 따라 매우 다양함을 알 수 있었다. 미국 CAP 2018년 기준을 따를 경우 3회차를 통한 참 여기관들의 정답률은 $57.6 \%-100.0 \%$ 로 회차당 평균 정답률은 93.0\%-97.7\%로 매우 우수하였다. 반면 오스트리아의 25년 간의 자료를 분석한 Koch와 Aberer [6]의 최빈도만을 허용범 위로 정한 기준 적용 시 $27.1 \%-93.2 \%$ 로 회차당 평균 정답률 은 $66.3 \%-76.0 \%$ 로 낮아졌다. 이러한 정답률은 동일한 기준을 적용한 오스트리아의 25 년 결과의 평균 $74.9 \%$ 와 유사한 결과 를 보였다[6]. 본 연구에서 각 기준 적용 시의 정답률의 상관 관계를 조사한 결과 $\mathrm{CAP}$ 기준과는 Koch와 Aberer [6]의 최 빈도 \pm 2 등급 기준 적용시와 가장 상관계수가 높았으나, 각 기 준에 따라 정답률에 차이가 보일 수 있으므로 평가자가 어떠한 기준을 선택할 것인지에 대해서는 충분히 고려할 필요가 있겠 다. 예를 들면 본 연구에서도 Table 1의 A기관은 CAP 기준에 서는 3 회차 모두 $100 \%$ 정답률을 보였음에도 Koch와 Aberer 〔6〕의 최빈도만을 허용기준으로 정한 경우에는 $46.2 \%, 66.7 \%$ 아 $89.7 \%$ 의 낮은 정답률을 보였기 때문이다.

Table 1 에서 보듯이 CAP 기준 적용 시 허용범위를 벗어난 기관들의 결과는 부적합 결과를 보인 항원의 개수에 상관없이 허용범위에 비하여 모두 일괄적으로 높거나 혹은 낮은 양상을 보였다. 부적합 결과를 보인 13 기관들의 결과가 허용범위보다 높은 결과는 6 기관, 낮은 결과는 7 기관으로 비슷하기는 하나, 이 중 부적합 결과가 25 개와 16 개를 보인 2 개 기관의 결과 중 60 개 항원 중 class I 이상을 보인 항원의 개수가 각 40 개, 43 개를 나타내었다(자료 제시하지 않음). 따라서 검사 후 양성을 보인 항원의 개수가 많을 경우에는 위양성 가능성을 배제하기 위하여 관련 기구 및 시약관리 등을 점검할 필요가 있겠다. 이 두 기관들은 이 이후에 평가에 참여하지 않아 추적할 수는 없 었다. 이러한 부적합 결과들은 특정 회차에 특정 기관에서 오 답을 배출하는 경향을 보였고, 부적합을 보인 모든 기관에서 부적합을 보인 양상은 다른 기관에 비하여 일괄적으로 높거나 혹은 낮거나 하는 양상을 보여주었으므로 시약의 특성이라기 보다는 검사과정이나 검사와 관련 있는 장비 및 기타 요인에 의한 것임을 알 수 있었다. 따라서 제품의 문제라기보다는 검 사실의 수기법이나 관련 기구를 점검할 필요가 있을 것으로 보 여졌다.

본 연구에서 부적합 결과들 중 허용범위에 비하여 높은 등급 을 보인 비율이 $72.1 \%$ (49/68) 그리고 낮은 등급을 보인 비율 이 27.9\% (19/68)로 전자가 더 많았다. 이러한 소견은 오스트 리아의 25 년간의 외부숙련도평가 결과분석에서 양성 검체의 위음성률은 $5.2 \%$ 인데 반하여 음성 검체의 위양성률은 $17.1 \%$ 
로 더 빈번하였다는 보고와 관련이 있다고 볼 수 있다[6]. 이 보고에서는 항원군에 따른 부적합 결과율은 각 항원군에 따 라 달랐는데 위양성률과 위음성률은 약물 $32.8 \%$ 와 $17.1 \%$, 독충 $21.7 \%$ 와 $3.8 \%$, 음식물 $15.9 \%$ 와 $8.8 \%$, 꽃가루 $15.3 \%$ 와 $2.8 \%$, 몰드 $11.5 \%$ 와 $8.4 \%$, 그리고 동물상피세포 $5.2 \%$ 와 $4.8 \%$ 로 위양성률이 더 높았으나, 환경물질의 경우 위음성이 $7.1 \%$ 로 위양성 $5.8 \%$ 보다 유일하게 높은 결과를 보였다고 하 였다. 비록 본 연구에서는 항원별로 검토하지는 못하였으나 부 적합을 보이는 항원은 식품형에 비하여 흡입형이 더 많았다.

유럽 외부숙련도평가 1997년 보고에서는 24 개의 결과에 대 하여 OMIS 값이 0은 가장 이상적이며 <3 만족이고 $>3$ 인 경 우에는 불량으로 간주하되 3 회 연속으로 $>3$ 인 경우를 지속적 인 불량으로 정의하였다[5]. 본 연구에서는 두 기관의 OMIS 값이 한 회차에 각각 4점을 보였으나 59 개 항원에 대한 것이라 는 점을 고려하고 이를 제외하고는 3점을 초과하는 기관이 없 었기에 3 회 동안 본 평가에 참여한 기관들이 양호한 결과를 보 였음을 알 수 있었다. 특히 OMIS 지수는 Koch와 Aberer [6] 의 부적합률과 높은 상관계수를 보여 부적합률을 보여주는 효 과적이면서 기관의 누적결과를 종합하여 참여기관의 수행률 을 평가할 수 있다는 것이 장점으로 여겨진다.

유럽 외부숙련도평가 1997년 보고에서 ImmunoCAP와 UniCap는 가장 낮은 오류값을 보였던 검사법으로 본 연구 에서 측정이 가능하였던 20 개 검체에 대하여 측정한 결과 Polycheck는 ImmunoCAP와 20개 중 3개에서 불일치 결과 를 보였으나 모두 한 등급 이내였다[5]. 유럽 외부숙련도평 가 1997년 보고에서는 class 0과 1은 음성으로 그 이상의 등 급은 양성으로 간주하였는데, 이 기준에 의하면 불일치를 보 인 3개의 검체들도 모두 ImmunoCAP의 양성과 음성 판정에 는 일치하였다[5]. 불일치를 보인 3종류의 항원들을 살펴보면 새우에 대하여 ImmunoCAP (f24)에서 class 1을 보인 반면 Polycheck는 f24/440 (shrimp mix)는 추가 항원을 가지고 있 는데 대다수 기관이 0으로 보고하여 ImmunoCAP 비하여 낮 게 측정되었기는 하나 모두 음성으로 판정이 가능하였므로, 양 성으로 판정되는 class 2 를 부적합 결과로 처리하는데 문제가 없었다. 또한 오랏(g03)과 땅콩(f13)은 각각 두 검체씩 비교 가 가능하였는데 이중 한 검체씩에서만 불일치를 보였으며, 이 러한 불일치도 검사실 간 비교의 허용범위가 ImmunoCAP의 결과처럼 모두 양성으로 판정이 가능하여 음성으로 판정하는 class 0 으로 보고한 부적합 기관을 평가하는 데 무리가 없었다 (Table 2).

RIDA allergy screen (R-Biopharm, Darmstadt, Germany), MAST optigen (Hitachi Chemical Diagnostics,
Mountain View, CA, USA), Polycheck를 ImmunoCAP 과 비교 평가한 국내 논문에서는 ImmunoCAP과의 일치 율이 양성 검체의 경우 각각 $45.7 \%, 88.2 \%, 28.6 \%$ 였으며, 음성 검체의 경우 $37.0 \%, 51.9 \%$ 와 $88.9 \%$ 로 보고하였다 [8]. 반면 MAST CLA allergy system (Hitachi Chemical Diagnostics), Allergy Screen (R-Biopharm, Germany), 그리고 Polycheck를 비교 평가한 다른 국내 논문에서는 Polycheck가 다른 두 시약과 동등하거나 우수하였다고 보고 하였다[2]. 본 연구에서 보듯이 동일한 검체에 대하여 동일 시 약으로 측정하여도 기관에 따라 그리고 평가시기에 따라 달라 질 수 있으므로, 알레르겐 특이 IgE 검사 시약의 평가 시는 특 정 lot에 대하여 한 기관에서만 측정하는 것보다는 한 기관에 서 여러 lot에 대하여 평가하거나 혹은 특정 lot에 대하여 평가 시는 최소 여러 기관에서 평가하는 것이 바람직할 것으로 여겨 졌다.

비록 본 연구에 참여한 기관 수가 많지 않았으므로 여러 가 지 평가기준 적용 시 참여기관 수가 많이 참여한 경우에 비하 여 평가의 신뢰도에 일부 영향을 미칠 수는 있겠으나, 알레 르겐 특이 $\mathrm{IgE}$ 검사의 외부숙련도평가가 없는 국내 현실에서 Polycheck 시약을 사용하는 검사실을 대상으로 처음으로 기관 간 평가를 실시하여 보고하였다는 데에 의의가 있겠다. 또한 등급을 평가하는 다양한 기준들을 소개하였고, 이러한 평가기 준에 따라서 정답률이 달라질 수 있음을 보여주어 평가기준 선 택의 중요성도 강조하였다. 이러한 소견들은 향후 국내에서 알 레르겐 특이 $\mathrm{IgE}$ 항체 검사의 검사실 간 평가를 실시하는데 도 움을 줄 수 있을 것으로 생각되었다.

\section{감사의 글}

이 연구는 2016년도 (주)원메디칼 임상연구비 지원에 의하여 이루어졌다(AJIRB-DEV-SUR-16-156).

\section{REFERENCES}

1. Reddy PM, Nagaya H, Pascual HC, Lee SK, Gupta S, Lauridsen JI, et al. Reappraisal of intracutaneous tests in the diagnosis of reaginic allergy. J Allergy Clin Immunol 1978;61:36-41.

2. Jang WR, Nahm CH, Kim JH, Lim DH, Jang TY, Moon YS, et al. Allergen specific IgE measurement with Polycheck Allergy: comparison of three multiple allergen simultaneous tests. Korean J Lab Med 2009;29:465-72. 


\section{Journal of LABORATORY MEDICINE and QUALITY ASSURANCE}

Young Ae Lim • Inter-Laboratory Comparison Using Polycheck

3. Jeong S, Jang GC, Cho NJ, Han MS, Kim HS, Sun JY, et al. Analysis of Polycheck Allergy results of the recent two years: comparison with skin prick test and ImmunoCAP. Lab Med Online 2012;2:139-47.

4. Kim HS. Tests for allergic disease. In: Korean Society Laboratory Medicine, editor. Laboratory medicine. 5th ed. Seoul: Panmun Education Co. Ltd., 2014:821.

5. Fifield R. Diagnostic allergy laboratory external proficiency testing in Europe. Methods 1997;13:33-42.
6. Koch L, Aberer W. Comparability and quality of IgEbased in vitro allergy diagnosis: 25 years of external quality assessment. Wien Klin Wochenschr 2014;126:634-41.

7. Lim HS, Kim HS, Oh H. Current status of serum allergen tests in Korea. Korean J Lab Med 2008;28:124-9.

8. Han M, Shin S, Park H, Park KU, Park MH, Song EY. Comparison of three multiple allergen simultaneous tests: RIDA allergy screen, MAST optigen, and polycheck allergy. Biomed Res Int 2013;2013:340513. 